

\section{The road to Brexit}

\section{MANCHESTER 1824}

Manchester University Press 
Ina Habermann - 9781526145093

Downloaded from manchesterhive.com at $04 / 26 / 2023$ 10:08:11AM 


\section{The road to Brexit}

\section{A cultural perspective on British attitudes to Europe}

Edited by

Ina Habermann

Manchester University Press 
While copyright in the volume as a whole is vested in Manchester University Press, copyright in individual chapters belongs to their respective authors, and no chapter may be reproduced wholly or in part without the express permission in writing of both author and publisher.

Published by Manchester University Press

Altrincham Street, Manchester M1 7JA

www.manchesteruniversitypress.co.uk

British Library Cataloguing-in-Publication Data

A catalogue record for this book is available from the British Library

ISBN 9781526145086 hardback

First published 2020

The publisher has no responsibility for the persistence or accuracy of URLs for any external or third-party internet websites referred to in this book, and does not guarantee that any content on such websites is, or will remain, accurate or appropriate.

COVER IMAGE: Dover cliffs, South Foreland Lighthouse, 2012.

Photo by Archangel12, via Wikimedia Commons, CC-BY-2.0

Typeset by Newgen Publishing UK 